\title{
SOBRE A ANGÚSTIA EM HEIDEGGER
}

\author{
da perspectiva existencial à ontológica
}

ABOUT THE ANGUISH IN HEIDEGGER

from the existential perspective to the ontological

\author{
Mariana Marcelino Silva Alvares ${ }^{l}$ \\ (maarimaarcelino@hotmail.com)
}

\begin{abstract}
RESUMO
No presente trabalho propomos apresentar o modo como Heidegger trata o conceito de angústia em sua aula inaugural Que é Metafísica?, enfatizando a relação entre o despertar da angústia e a revelação do ser. Ao mesmo tempo, propomos confrontar o tratamento do conceito de angústia na preleção e aquele que Heidegger dá ao conceito em Ser e Tempo. Com efeito, em sua preleção Heidegger apresenta a angústia como uma manifestação do nada, na qual ocorre a revelação do ente enquanto tal para o ser-aí. Por outro lado, no $\S 40$ de Ser e Tempo Heidegger apresenta a angústia como a disposição que retira o ser-aí da decadência e o singulariza, ou seja, o coloca diante de si mesmo. Com isso, mostraremos os desdobramentos do conceito de angústia, desde a abordagem mais existencial do tratado maior até a perspectiva mais ontológica da preleção.
\end{abstract}

Palavras-chave: Angústia. Ser-aí. Ser.

\begin{abstract}
In the present work we propose to present the way in which Heidegger treats the concept of anguish in his inaugural class What is Metaphysics?, emphasizing the relation between the awakening of anguish and the revelation of being. At the same time, we propose to confront the treatment of the concept of anguish in the lecture and the one that Heidegger gives to the concept in Being and Time. Indeed, in his lecture Heidegger presents anguish as a manifestation of nothingness, in which the revelation of the being as such to the Dasein occurs. On the other hand, in $\S 40$ of Being and Time Heidegger presents anguish as the disposition that removes Dasein from de-cadence and singularizes it, that is, places it before itself. With this, we will show the unfolding of the concept of anguish, from the most existential approach of the major treatise to the more ontological perspective of the lecture.
\end{abstract}

Keywords: Anguish. Dasein. Being.

\section{INTRODUÇÃO}

\footnotetext{
${ }^{1}$ Graduanda em Filosofia pela Universidade Estadual de Santa Cruz (UESC). CV Lattes: http://lattes.cnpq.br/8257922893350760. ORCID: https://orcid.org/0000-0002-1053-4300.
} 
Em Ser e Tempo (1927) Heidegger desenvolve uma análise existencial enquanto via para se alcançar o modo adequado de se colocar em questão o ser. Desse modo, o que Heidegger busca em Ser e Tempo é o desenvolvimento da questão sobre o ser. Tendo em vista o objetivo de colocar a questão do ser, Heidegger, já de início, dá uma pista sobre o caminho a ser traçado ao afirmar que na pergunta pelo que é ser, já se tem sobre o ser uma précompreensão. De fato, na questão “o que é ser” o sentido do ser já está, de algum modo, disponível para quem pergunta, pois já temos sempre alguma compreensão do "é”. De início, e na maior parte das vezes, portanto, quem pergunta sobre o ser caminha, mesmo que de maneira vaga e mediana, na compreensão do ser. Segundo isso, diz Heidegger:

Enquanto procura, o questionamento necessita de uma orientação prévia do procurado. Para isso, o sentido do ser já nos deve estar, de alguma maneira, disponível. Já se aludiu: nós nos movemos sempre numa compreensão do ser. É dela que brota a questão explícita do sentido do ser e a tendência para o seu conceito. Nós não sabemos o que diz 'ser'. Mas já quando perguntamos o que é 'ser' nós nos mantemos numa compreensão do 'é', sem que possamos fixar conceitualmente o que significa esse 'é'. (HEIDEGGER, 2002, p. 31)

O que Heidegger pretende é, a partir dessa pré-compreensão do ser, vaga e mediana, alcançar o modo adequado de se colocar a pergunta pelo sentido do ser. Por isso a précompreensão do ser seria o ponto de partida.

Pois bem, na pergunta pelo que é o ser, segundo Heidegger, há três elementos constitutivos, a saber, o questionado, o perguntado e o interrogado. Ora, segundo Heidegger, na pergunta pelo ser o questionado é o ser. O que se pergunta, por sua vez, o perguntado é o sentido do ser. E aquele que pergunta, isto é, o interrogado é o ente. Interroga-se o ente a respeito de qual é, do ser, o seu sentido.

Mas qual é o ente que deve ser interrogado acerca do sentido do ser? Heidegger parte do ente que pergunta pelo ser, e na pergunta, o compreende de maneira vaga e mediana. A tal ente Heidegger nomeia Dasein / ser-aí. O ser-aí é o ente, além disso, para o qual está em jogo seu ser. Com efeito, segundo Heidegger, o ser-aí, sendo, possui uma relação com o ser. Essa relação faz do ser-aí um ente privilegiado, pois em seu modo de ser, mesmo que de maneira vaga, o ser-aí compreende e pergunta pelo ser. Sobre isso, diz Heidegger:

$\mathrm{Na}$ tarefa de interpretar o sentido do ser, a presença não é apenas o ente a ser interrogado primeiro. É, sobretudo, o ente que, desde sempre, se relaciona e comporta com o que se questiona nessa 
questão. A questão do ser não é senão a radicalização de uma tendência ontológica essencial, própria da presença, a saber, da compreensão preontológica do ser. (HEIDEGGER, 2002, p. 41)

Essa compreensão pré-ontológica do ser-aí e sua remissão à questão do ser faz do seraí um ente em alguma sintonia com o ser. Tendo em vista isso, Heidegger expõe em Ser $e$ Tempo a analítica existencial do ser-aí, explicitando os elementos ontológicos constitutivos do existente humano. O intuito dessa análise é liberar o caminho para se colocar a questão sobre o ser. Se o ser-aí é o ente que, sendo, se relaciona com o ser, é a partir desse ente que Heidegger inicia o percurso de Ser e Tempo.

Ora, na analítica existencial do ser-aí feita por Heidegger as estruturas que se referem à constituição ontológica do ser-aí o filósofo denomina de existenciais. Dentre os existenciais descritos por Heidegger em Ser e Tempo está a disposição, a qual se refere à maneira como o ser-aí se abre humoradamente ao mundo. O que ontologicamente Heidegger denomina como disposição, onticamente é geralmente entendido como estado de humor - sentimentos e afetos. O termo disposição, porém, diz respeito à abertura humorada do ser-aí ao mundo. Com efeito, segundo Heidegger: “o humor revela 'como alguém está e se torna'. É nesse 'como alguém está' que o humor conduz o ser para o seu 'pré'” (HEIDEGGER, 2002, p. 188).

Entre as disposições de humor que Heidegger apresenta em Ser e Tempo, nos ocuparemos, no presente trabalho, da angústia. Trataremos da angústia dando destaque às sutis diferenças dos modos como Heidegger a expõe em Ser e Tempo e na preleção Que é metafísica? (1929). O objetivo do trabalho é expor a mudança de perspectiva no tratamento do conceito de angústia, investigando, sobre esse conceito, as aproximações e distâncias entre as duas obras. Com efeito, Macdowell, em sua obra A gênese da ontologia fundamental de Martin Heidegger, afirma que há uma diferença essencial entre a análise do fenômeno da angústia em Ser e Tempo e em Que é Metafísica? Apesar de ambos os textos entenderem que a angústia seria provocada pelo nada, em Ser e Tempo seria o ser-no-mundo como tal que se manifestaria através do nada, mediante a insignificância do ente. Com efeito, uma vez retirada as possibilidades de interpretação a partir do ente, o ser-aí seria colocado diante de seu poder ser mais próprio, de maneira que "a experiência do nada das possibilidades intramundanas põe a descoberto o autêntico ser do eis-aí-ser" (MACDOWELL, 1970, p. 163). Por sua vez, em Que é Metafísica?, seria o ente em seu todo que se manifestaria através do nada e isso de tal maneira que “o nada que resta não é senão o ser, como o 
absolutamente outro em relação ao ente no seu todo" (MACDOWELL, 1970, p. 163). Não pretendemos afirmar que há uma ruptura radical entre os dois textos, mas uma ligeira diferença no tratamento do fenômeno. De fato, em Ser e Tempo Heidegger apresenta a angústia segundo uma perspectiva existencial, entendendo-a como disposição que aproxima o ser-aí de si mesmo, retirando-o da impessoalidade e remetendo-o à autenticidade. Por sua vez, na preleção Que é Metafísica o filósofo pensa o conceito de angústia enfatizando a relação entre o despertar da angústia e a revelação do ser.

Ora, o pesquisador americano Richardson igualmente, em seu estudo sobre o pensamento heideggeriano, afirma que embora não haja uma mudança radical no texto Que é Metafísica? em relação ao tratado maior, é possível, porém, perceber uma diferença de perspectiva no tratamento do conceito. Essa diferença se evidenciaria de tal maneira que o comentador afirma que a preleção Que é Metafísica? pode ser caracterizada como uma obra de transição (RICHARDSON, 2003, p. 195). Com efeito, a angústia é tratada na preleção como a disposição que possibilita a manifestação do nada no ser-aí. O nada, por sua vez, é entendido como o acontecimento que possibilita o desvelar dos entes em sua totalidade. É pela manifestação do nada, portanto, que os entes se tornam acessíveis. Ao contrário, em Ser $e$ Tempo o conceito de angústia é tratado como a disposição que possibilita ao ser-aí ser si mesmo, no sentido da autenticidade. Não nos parece de todo descabido, portanto, sugerir uma ligeira diferença de perspectiva entre essas duas obras.

\section{SER E TEMPO: A ANGÚSTIA EXISTENCIAL}

Pois bem, antes de adentrarmos na descrição de Heidegger da disposição da angústia, se faz preciso, a título de esclarecimento, discorrer brevemente a respeito do modo de ser cotidiano do ser-aí, isto é, do modo em que ele é de início e na maior parte das vezes, enquanto, portanto, decaído e guiado pelo que o filósofo denomina de impessoal. Com efeito, o ser-aí é um ente que vive em meio a outros entes, mundanos e intramundanos.

Ora, do ser-aí faz parte, enquanto componente ontológico-existencial, o que o filósofo denomina no tratado de ser-com os outros de si mesmo. Esses outros, segundo Heidegger, "são aqueles dos quais, na maior parte das vezes, ninguém se diferencia propriamente, entre os quais também se está." (HEIDEGGER, 2002, p. 170). O ser-aí é, pois, ser-com os outros e nessa convivência é frequentemente exposto ao constrangimento de ser 
como os outros. Essa não é uma característica ocasional da existência; ao contrário, o ser-aí é, como já dito, ontologicamente ser-com outros ser-aí.

De acordo com isso, na medianidade o ser-aí, no lidar com os outros ser-aí, está sob os ditames daquilo que o filósofo denomina de impessoal, isto é, uma voz neutra e disseminada que determina o que se deve fazer ou pensar, de acordo com aquilo que "todo mundo" faz e pensa. Impelido pelos afazeres da ocupação o ser-aí, na cotidianidade, é como os outros são. Nesse sentido, na cotidianidade o ser-aí interpreta os sentidos e os significados segundo o faz todo mundo. Ao pegar um transporte público, ao frequentar um restaurante, ao ir trabalhar o ser-aí é como todo mundo. Decaído no mundo, na convivência com outros entes, o ser-aí vive como todo mundo vive.

No entanto, esse ser como os outros guiado pelo impessoal não quer dizer ser como alguém, mas ser como ninguém. O impessoal nivela o modo de ser do ser-aí, pois no impessoal se é como todo mundo, mas "todo mundo" não se refere a pessoa alguma. Caso se perguntasse "quem é todo mundo?” a resposta seria ninguém. Para Heidegger: "o impessoal, que não é nada determinado, mas que todos são, embora não como soma, prescreve o modo de ser da cotidianidade." (HEIDEGGER, 2002, p. 179). Portanto, o ser-aí na cotidianidade é como ninguém.

Esse modo de ser da cotidianidade, segundo Heidegger, resulta em um nivelamento das possibilidades de ser. Na medida em que o ser-aí, junto com os outros é, na cotidianidade, como eles, as suas possibilidades de ser se nivelam àquelas de todo mundo. Sobre isso, diz Heidegger: "na utilização dos meios de transporte público, no emprego dos meios de comunicação e notícias (jornal), cada um é como o outro.” (HEIDEGGER, 2002, p. 179).

De acordo com isso, o impessoal afasta o ser-aí de sua propriedade. Em sentido ontológico, a propriedade, segundo Heidegger, se acha obstruída e fechada na decadência, isto é, na queda que caracteriza a medianidade. Diz Heidegger: "do ponto de vista existenciário, sem dúvida, a propriedade do ser-próprio se acha, na decadência, obstruído e fechado." (HEIDEGGER, 2002, p. 248).

Nessa fuga de si mesmo em que se é como todo mundo, a responsabilidade pelas ações se transfere para "todo mundo". Pois no nivelamento das possibilidades de ser o ser-aí tira de si o encargo de suas ações. Já que se é como todo mundo, a responsabilidade pelas decisões não é minha, mas de todo mundo. O problema é que, como já vimos anteriormente, "todo mundo" é uma generalização sem rosto. Em outras palavras, na convivência com os outros entes no impessoal o ser-aí não assume responsabilidade pelo que é. 
Apesar disso, na maior parte das vezes é no modo de ser do impessoal que o ser-aí existe enquanto ser-no-mundo. É uma condição ontológica do ser-aí, enquanto ser-no-mundo, existir no impessoal. Isso não diz respeito a uma escolha moral - não se escolhe estar ou não no impessoal. Imerso nesse modo de ser, o ser-aí se encontraria, na maior parte das vezes, na inautenticidade, ou seja, sendo impróprio. É necessário enfatizar, porém, que os termos autêntico e inautêntico não possuem sentido moral. Ser moralmente bom não quer dizer ser autêntico, assim como ser moralmente ruim não quer dizer ser inautêntico. Tendo em vista que na cotidianidade o ser-aí existe em geral no modo de ser do impessoal, na maior parte das vezes, o ser-aí estaria na inautenticidade, isto é, segundo o que diz e pensa a voz neutra e impessoal de "todo mundo". Essa inautenticidade expressa, segundo Heidegger, o nivelamento das possibilidades de ser que faz do ser-aí assim como todo mundo. Por sua vez, a autenticidade se refere às possibilidades próprias de o ser-aí ser próprio.

No entanto, estar na autenticidade não significa sair do impessoal para alcançar um modo de ser-no-mundo mais próprio. Ao contrário, essa possibilidade de o ser-aí ser próprio, se alcançada, não significa um rompimento definitivo com o impessoal. Sobre isso, diz Heidegger: "o ser do que é próprio não repousa num estado excepcional do sujeito que se separou do impessoal. Ele é uma modificação existenciária do impessoal como existencial constitutivo." (HEIDEGGER, 2002, p. 183).

Haveria, pois, uma modificação do impessoal quando o ser-aí defronta-se com sua propriedade. Diante disso, surge-nos a questão de saber como o ser-aí, imerso no impessoal, pode ser em sentido próprio. A sugestão dada por Heidegger em Ser e Tempo estaria na descrição da disposição da angústia. Desse modo, seria pela disposição da angústia que o seraí poderia se abrir em sentido próprio. Essa disposição, portanto, seria fundamental na medida em que abre, para o ser-aí, a possibilidade de ser em sentido autêntico.

No entanto, para explicitar o sentido da angústia tal como é pensada em Ser e Tempo se faz importante esclarecer brevemente sobre uma das estruturas ontológicas do ser-aí já mencionada na introdução desse trabalho, a saber, a disposição. Em seu sentido ontológico a disposição se refere à maneira como o ser-aí se abre humoradamente ao mundo. Onticamente, por sua vez, a disposição é o que se entende como estado de humor. No entanto, a disposição diz mais do que estado de humor. Com efeito, a disposição conduz o ser do ser-aí à sua abertura. Nessa condução o ser-aí está entregue ao fato de que é, e, uma vez sendo, ao fato de que tem de ser. Sem saber de sua origem ou de seu destino, se era antes de existir, ou se continuará sendo depois de deixar de ser, o ser-aí abre-se para si mesmo 
como o ente que é, e, sendo, tem que ser. A esse fato Heidegger denomina de facticidade, a qual revela o estar-lançado do ser-aí para a abertura que se dá, pela disposição, de maneira humorada. Sobre a facticidade diz Heidegger:

Esse 'fato de ser' [...] encoberto em sua proveniência e destino, mas tanto mais aberto em si mesmo quanto mais encoberto, chamamos de estarlançado em seu pre, no sentido de, enquanto ser-no-mundo, esse ente ser sempre o seu pre. A expressão estar-lançado deve indicar a facticidade de ser entregue à responsabilidade. (HEIDEGGER, 2002, p. 189, grifo nosso)

Com efeito, a disposição de humor abre o ser-aí através de envios e desvios e não por meio de observação teórica. Esse modo de abrir o ser-aí em seu estar-lançado ocorreria por desvios que se esquivam. Esse desvio, na maior parte das vezes, faz pouco caso do caráter pesado em que o ser-aí se revela.

Ora, para Heidegger seria um equívoco fenomenal identificar com a disposição de humor o que se abre e como se abre com aquilo que o ser-aí comumente sabe e acredita (HEIDEGGER, 2002, p. 190). Ao invés disso, para o filósofo, a disposição colocaria o ser-aí diante da abertura que se apresenta como um enigma inexorável. É por isso que não se pode compreender a disposição a partir do que se acredita ou do que se sabe, pois tal compreensão não alcançaria o sentido ontológico da disposição. Apesar da ânsia de tentar se assenhorar, por meio do conhecimento, do humor, a apreensão teórica não seria adequada para o acesso ao fenômeno da disposição. Pois antes de qualquer teorização acerca do humor, a disposição já se encontra provocando a abertura do ser-aí. De fato, a disposição é tão pouco reflexiva que faz com que o ser-aí se precipite “para o mundo". Antes de qualquer reflexão, a disposição já abre o ser-aí, no mundo, de maneira humorada. Sobre isso, diz Heidegger:

O humor se precipita. Ele não vem de 'fora' nem de 'dentro'. Cresce a partir de si mesmo como modo de ser-no-mundo. Com isso, porém, passamos de uma delimitação negativa da disposição frente à apreensão reflexiva do 'interior' para uma compreensão positiva de seu caráter de abertura. $O$ humor já abriu o ser-no-mundo em sua totalidade e só assim torna possível um direcionar-se para (...). (HEIDEGGER, 2002, p. 191, grifo nosso)

Por meio desses envios e desvios a disposição permitiria ao ser-aí a compreensão de estar entregue à responsabilidade de seu ser. A disposição que revela ao ser-aí seu estarlançado abre, também, o ser-no-mundo. Sendo assim, a disposição não se refere, segundo Heidegger, a um estado psíquico que se exteriorizaria de maneira enigmática. Ao invés disso, a disposição "é um modo existencial básico da 
abertura igualmente originária de mundo, de co-presença e existência, pois também este modo é em si mesmo ser-no-mundo" (HEIDEGGER, 2002, p. 191, grifo nosso).

Tendo isso em vista, Heidegger, visando descortinar o horizonte ôntico em que o seraí se encontra na maior parte das vezes, se debruça, em Ser e Tempo, sobre uma disposição em específico. Essa disposição, que para o filósofo pode explicar o próprio ser-aí como ente, é a angústia. Segundo Heidegger, a angústia é uma disposição fundamental que abre de maneira privilegiada o ser do ser-aí. Nesse sentido, se para alcançar a propriedade do ser-aí seria preciso partir de sua abertura constitutiva, o caminho traçado por Heidegger atravessaria a abertura privilegiada da angústia. Por isso, o filósofo se ocupa no $\$ 40$ em explicitar o sentido ontológico da angústia.

Essa tarefa se concretiza inicialmente mediante a comparação da angústia com outra disposição de humor, qual seja, o temor. Tendo em vista que há algumas semelhanças entre essas disposições que poderiam originar confusões conceituais, o filósofo decide discorrer sobre a angústia diferenciando-a do temor. Ao contrário do temor, assim, a angústia seria uma disposição fundamental que abriria de maneira privilegiada o ser do ser-aí.

De acordo com isso, Heidegger se dedica então a aparente semelhança entre a disposição da angústia e a disposição do temor. Com efeito, tanto a angústia quanto o temor são desencadeados por um ameaçador. Sendo assim, quando tomado pelo temor o ser-aí foge, assim como na angústia.

No entanto, aquilo que ameaça difere na disposição da angústia e na disposição do temor. Enquanto na disposição do temor o ameaçador é um ente intramundano determinado, na angústia o ente que ameaça possui o modo de ser do que se retira. Em outras palavras, o que ameaça não é nenhum ente determinado, mas antes a ameaça se encontra no ser-aí ele mesmo. No impessoal, com efeito, o ser-aí existe segundo o modo de uma fuga. Essa fuga, no entanto, não é de algum ente intramundano determinado. O ser-aí, acomodado no impessoal, foge de si mesmo, de um encontro com si mesmo. Essa fuga de si seria ontologicamente constitutiva do ser-aí. Nesse sentido, segundo Heidegger, aquilo com que o ser-aí se angustia não é senão o ser-aí ele mesmo em seu ser-no-mundo.

A partir dessas análises já se pode estabelecer diferenças entre a disposição fundamental da angústia e a disposição do temor, apesar de as duas possuírem o mesmo parentesco fenomenal. Na disposição do temor aquilo de que o ser-aí teme é um ente intramundano determinado. Segundo isso, diz Heidegger: "a única ameaça que pode tornar-se 'temível' e que se descobre no temor provém sempre de algo 
intramundano" (HEIDEGGER, 2002, p. 249). Por isso, quando alguém diz ter medo, esse medo é acompanhado de um algo que ameaça. Sendo assim, o temor seria sempre temor de algo determinado. Na angústia, porém, não há com que o ser-aí se angustiar. Sobre isso, diz Heidegger

\begin{abstract}
A ameaça não possui o caráter de um determinado dano que diria respeito ao ameaçado na perspectiva determinada de um específico poder-ser de fato. O com quê da angústia é inteiramente indeterminado. Essa indeterminação não apenas deixa indefinido de fato que ente intramundano 'ameaça' como também diz que o ente intramundano é 'irrelevante'. (HEIDEGGER, 2002, p. 250)
\end{abstract}

Por outro lado, o ser-aí, na disposição da angústia, além de não se angustiar por algum ente intramundano determinado, percebe o mundo circundante enquanto desprovido de relevância. A ameaça da angústia, por não surgir de algum ente determinado, não possui lugar de onde seria disparada. Por isso, segundo Heidegger, "o que caracteriza o referente da angústia é o fato do ameaçador não se encontrar em lugar algum" (HEIDEGGER, 2002, p. 250, grifo nosso). Em lugar algum situa-se a abertura de mundo. Com efeito, segundo Heidegger, a angústia abre o mundo como mundo. Na angústia os entes intramundanos que se encontram à mão no mundo circundante perdem a significância que caracteriza o encontro mundano com os entes. Sobre isso, diz Heidegger: "na angústia o que se encontra à mão no mundo circundante, ou seja, o ente intramundano em geral, se perde" (HEIDEGGER, 2002, p. 251). Todos os entes se nivelariam e o que se abriria enquanto tal, na angústia, seria o mundo ele mesmo. Tendo em vista que na disposição da angústia os entes intramundanos são insignificantes, é o mundo como tal que se abre para o ser-aí. Desse modo, o com que da angústia, segundo Heidegger, é o mundo como tal, isto é: "a angústia se angustia com o mundo como tal" (HEIDEGGER, 2002, p. 250). Nesse sentido, a angústia abriria o mundo como mundo. Isso significa que a angústia se angustia com o próprio ser-no-mundo como tal.

Pois bem, o ser-aí tomado pela disposição da angústia, assim como em toda disposição, revelaria a si mesmo como é e está. Com efeito, segundo Heidegger, as disposições revelam como o ser-aí está. E já que a disposição revelaria como se está, o ser-aí, quando tomado pela disposição da angústia, se sentiria estranho. A estranheza se funda no fato de a disposição abrir o mundo enquanto tal. Assim assaltado pela angústia, o ser-aí perderia a familiaridade que caracteriza o lidar cotidiano e impessoal com os entes e os outros. Ao sentir-se estranho diante do mundo como tal, o ser-aí, na disposição da angústia, existiria segundo um modo que o filósofo denomina de 
"não se sentir em casa". Diz Heidegger: “[...] estranheza significa igualmente "não se sentir em casa"” (HEIDEGGER, 2002, p. 252).

Com efeito, a angústia retira do ser-aí a possibilidade de ele se compreender segundo os entes intramundanos que estão no mundo. A tranquilidade comum ao ser-aí no impessoal se esvai, quando tomado pela angústia, dando lugar a um estranho não se sentir em casa. $\mathrm{O}$ que se impõe na disposição da angústia é o mundo como tal que abre o ser-aí enquanto um ente de possibilidades. Na angústia, o ser-aí se abre como o ente que somente a partir de si mesmo pode se singularizar (HEIDEGGER, 2002, p. 252). No entanto, essa afirmação não postula um solipsismo existencial em que o ser-aí na disposição da angústia estaria amarrado. Com efeito, esse sentir-se estranho e a condição de estar entregue à possibilidade de sua singularização própria não significa o mesmo que o ser-aí estar isolado "no vazio inofensivo de uma ocorrência desprovida de mundo" (HEIDEGGER, 2002, p. 252). Ao invés disso, o ser-aí na disposição da angústia se abre enquanto ser-no-mundo, isto é, enquanto ente que se relaciona com os demais entes e com os outros de si. O que se explicita seria o mundo enquanto tal.

Ao abrir-se, para o ser-aí tomado pela disposição da angústia, o mundo enquanto tal e ao se desvelar, por essa disposição, o fato de que o ser-aí é originariamente poder-ser, a fuga do ser-aí não seria de um ente intramundano, mas para esse ente. Com efeito, o ser-aí na disposição da angústia estaria na fuga para os entes, isto é, para a tranquilidade e familiaridade características do modo de ser do impessoal. Nesse sentido, a fuga em que o ser-aí se encontra seria a fuga da estranheza da angústia, uma fuga em direção à tranquilidade do impessoal. O ser-aí foge, na maior parte das vezes, para os entes, ou seja, para a tranquilidade familiar do impessoal. Do que foge, no entanto, é da ameaça de se abrir como um si mesmo singular. Sobre isso, diz Heidegger: "o ser-no-mundo tranquilizado e familiarizado é um modo da estranheza da presença e não o contrário. $O$ não sentir-se em casa deve ser compreendido, existencial e ontologicamente como o fenômeno mais originário" (HEIDEGGER, 2002, p. 254, grifo nosso).

Tendo em vista que, na maior parte das vezes, o ser-aí estaria imerso no mundo das ocupações e guiado pela voz neutra do impessoal, ser assaltado pela disposição da angústia seria, segundo Heidegger, raro e fugidio. A raridade do fenômeno, porém, seria um indício de que o ser-aí permanece encoberto para si mesmo e que pela disposição da angústia tem a 
possibilidade de se abrir em sentido originário (HEIDEGGER, 2002, pp. 254-255). Isso significa que a disposição da angústia seria uma disposição fundamental, pois abriria o ser-aí em seu poder-ser mais próprio. Sobre isso, diz Heidegger:

Na verdade, pertence à essência de toda disposição abrir, cada vez, todo o ser-no-mundo, segundo todos os seus momentos constitutivos (mundo, serem, ser-próprio). Só na angústia subsiste a possibilidade de uma abertura privilegiada na medida em que ela singulariza. Essa singularização retira a presença de sua decadência e lhe revela a propriedade e impropriedade como possibilidades de seu ser. (HEIDEGGER, 2002, p. 255)

De acordo com isso, a disposição da angústia seria fundamental, pois abriria o ser-aí enquanto possibilidade de ser e com isso revelaria a possibilidade de o ser-aí ser em sentido próprio ou impróprio. A angústia em Ser e Tempo, portanto, se localizaria no abrir-se do seraí a suas possibilidades de ser e, com isso, no abrir-se da possibilidade de o ser-aí ser em sentido próprio. Essa abertura seria privilegiada por colocar o ser-aí diante de seu ser mais próprio, diante do fato de ser um ente de possibilidades de ser, um si mesmo singular. Na angústia, além disso, os entes com os quais o ser-aí lida na ocupação cotidiana perderiam a relevância e o mundo se abriria enquanto mundo e o ser-aí ele mesmo enquanto ser-nomundo.

\section{QUE É METAFÍSICA: A ANGÚSTIA ONTOLÓGICA}

Em sua preleção de 1929, Que é Metafísica?, Heidegger se propõe a discutir o que é metafísica a partir de dentro da própria metafísica. Para tanto, o filósofo coloca em questão o nada e busca pensá-lo segundo a disposição da angústia.

$\mathrm{Na}$ aula inaugural, pois, Heidegger defende que para problematizar a metafísica é necessário fazê-lo de dentro, o que significa trazer à tona uma questão metafísica. Nesse sentido, a resposta à questão da preleção, isto é, a questão a respeito do que é a metafísica, não poderia ser obtida a partir de uma solução exterior tal como "a metafísica é isto ou aquilo" - ou seja, a partir de um questionamento simplesmente sobre a metafísica -, pois, nesse caso, a metafísica estaria sendo visada desde fora. Por outro lado, o questionamento metafísico, segundo o filósofo, coloca em questão igualmente aquele que interroga.

Sendo assim, a pergunta sobre o nada seria uma questão metafísica, pois problematiza a metafísica desde dentro, isto é, a partir de uma questão metafísica, e 
nessa questão, além disso, aquele que interroga, ou seja, o ser-aí também é interrogado em seu ser.

Pois bem, a questão metafísica que o filósofo se propõe pensar então é a pergunta sobre o nada, mas Heidegger desde o início problematiza o modo como se interroga pelo nada, pois perguntar o que é "nada" já pressupõe o nada como algo que é. E tendo em vista que o nada, que é entendido comumente como a negação da totalidade do ente, não pode ser algo que "é", a questão de antemão cairia em contrassenso. Diante disso, o filósofo exprime a necessidade de se afastar do domínio da lógica tradicional para se pensar tal questão de maneira que não se reduza o nada a um ente ou à negação. Diz o filósofo: “[...] nós afirmamos: o nada é mais originário que o ‘não’ e a negação” (HEIDEGGER, 1979, p. 37).

Já que o nada nem pode ser um ente, nem pode ser mera negação, como se perguntar e se pensar sobre o nada? Diante de tal problema, Heidegger afirma: o nada acontece. Com isso, o filósofo nos propõe pensar o nada como um acontecimento - acontecimento que, como o filósofo expõe durante a preleção, se tornaria visível a partir da disposição fundamental da angústia. O nada, nesse sentido, acontece no ser-aí e se torna patente quando este é assediado pela disposição da angústia. Esse acontecimento, segundo Heidegger, apesar de possível e real é bastante raro e se dá apenas por instantes.

A angústia, no entanto, não pode ser entendida, segundo Heidegger, como o medo de alguma coisa. E assim como ele fez em seu tratado maior, na preleção o filósofo distingue a angústia do temor. Essa diferença é fundamental e ontológica, pois o ser-aí, quando na disposição do temor, tem temor de algum ente determinado que o ameaça. Sobre isso, diz o filósofo: "nós nos atemorizamos sempre diante deste ou daquele ente determinado que, sob um ou outro aspecto determinado, nos ameaça. O temor de [...] sempre teme por algo determinado" (HEIDEGGER, 1979, p. 39, grifo nosso).

Por sua vez, a angústia não é angústia diante de algum ente determinado, mas angústia diante de algo indeterminado, que não se sabe o quê. A respeito disso, já o filósofo dissera em Ser e Tempo: "o com quê da angústia é inteiramente indeterminado. Essa indeterminação não apenas deixa indefinido de fato que ente intramundano 'ameaça' como também diz que o ente intramundano é 'irrelevante"” (HEIDEGGER, 2012, p. 250).

Essa angústia diante do que não se sabe, ao contrário do temor, desperta no ser-aí uma estranha tranquilidade. Por isso, segundo Heidegger, quando estamos tomados pela disposição da angústia é comum dizermos "a gente sente-se estranho". Mas se sente estranho diante de quê? Não há um diante de quê, pois na angústia todos os entes, inclusive 
nós, afundamos em uma indiferença. Essa indiferença, entretanto, não significa um desaparecimento dos entes. Tal afastamento nos assedia e nos oprime, na medida em que os entes, na angústia, se tornam caducos e se revelam como entes que simplesmente são. É nesse sentido que, segundo Heidegger, a disposição da angústia revela o nada.

Com efeito, é nessa disposição de humor que o nada se manifesta, porque é ela que retira a familiaridade com os entes e os desvelam como entes que são. Na angústia não há algo em que se apoiar. Diz Heidegger: "[...] somente continua presente o puro ser-aí no estremecimento deste estar suspenso onde nada há em que apoiar-se" (HEIDEGGER, 1979, p. 39). A angústia possibilita para o ser-aí a experiência do desvelamento dos entes como entes que estão aí. Não há, como na cotidianidade, um para quê determinado. Por isso, a mesa perde o sentido, a cadeira perde o sentido, o martelo perde o sentido; os entes, na insignificância, se nivelam na indiferença, diante da qual o ser-aí se espanta com o puro fato de que eles simplesmente são.

Consequentemente, não há o que falar quando tomados pela angústia. Diz Heidegger: “a angústia nos corta a palavra" (HEIDEGGER, 1979, p. 40). E isso acontece porque os entes em sua totalidade ${ }^{2}$ fogem, e com isso foge também a possibilidade de se lidar com o ente como algo que é para tal função. O que resta a dizer é uma sucessão de palavras desarticuladas e sem sentido. Tal característica de perda de fala justifica o que Heidegger pretende mostrar na preleção, a saber, que a angústia manifesta o nada. Essa manifestação é testemunhada ainda quando a angústia se afasta do ser-aí. Pois após o assédio da angústia, mas ainda tomado pela lembrança dessa disposição, o ser-aí comumente afirma que "diante de que e por que nós nos angustiávamos era 'propriamente' - nada. Efetivamente: o nada mesmo - enquanto tal - estava aí” (HEIDEGGER, 1979, p. 40).

A revelação do nada pela angústia, contudo, não significa que ele se revela enquanto ente ou objeto. Com efeito, é a angústia que manifesta o nada, mas manifesta como constitutivo fundamental do ser-aí. O nada se revela na angústia juntamente com o ente em sua totalidade. Mas o que significa esse juntamente com?

Sobre isso, diz Heidegger:

Somente na clara noite do nada da angústia surge a originária abertura do ente enquanto tal: o fato de que é ente - e não nada. Mas este 'e não nada',

\footnotetext{
${ }^{2}$ A totalidade dos entes não diz respeito naturalmente ao conjunto de tudo o que existe. No âmbito do presente trabalho não nos é possível discutir mais demoradamente sobre o que significa estar situado em meio à totalidade do ente, mas indicamos sobre o assunto a leitura do texto do professor Róbson Reis: REIS, R. R.. Natureza e normatividade na hermenêutica ontológica de Martin Heidegger - parte I e II. Natureza Humana, v. 12(1), p. 954, 2010.
} 
acrescentado em nosso discurso, não é uma clarificação tardia e secundária, mas a possibilitação prévia da revelação do ente em geral. (HEIDEGGER, 1979, p. 41)

Nessa perspectiva, seria o nada que possibilitaria a revelação do ser dos entes. E é ele, em sua essência nadificante que pela angústia conduz o ser-aí para o ente enquanto tal. Segundo isso, diz Heidegger: "ser-aí quer dizer: estar suspenso dentro do nada" (HEIDEGGER, 1979, p. 41).

Diante disso, mostra-se que a angústia enquanto manifestação do nada revela o ser, tendo em vista que o nada nem é um objeto, nem é um ente, mas um acontecimento que manifesta os entes enquanto tal - é um outro de todo ente, ou seja, o ser ${ }^{3}$. Sobre isso, diz Heidegger: "o nada não é um conceito oposto ao ente, mas pertence originariamente à essência mesma (do ser). No ser do ente acontece o nadificar do nada" (HEIDEGGER, 1979, p. 41).

Apesar disso, segundo o filósofo, nós não podemos nos colocar originariamente diante do nada por decisão própria. Resta apenas a expectativa e a prontidão para a angústia, a qual, no período da preleção, se apresentava para o filósofo como um modo fundamental de se abrir para o ser dos entes. A angústia nos afeta como num lampejo e após tal experiência, o que nos resta à fala é que "o que nos afetou era nada".

Por fim, a análise do tratamento que a preleção dá ao conceito de angústia nos possibilita perceber uma ligeira diferença de tratamento em relação à analítica de Ser $e$ Tempo. Enquanto em Ser e Tempo a descrição do conceito de angústia perpassaria a analítica existencial do ser-aí, na preleção de 1929 a angústia revela o nada enquanto o outro do ente, isto é, o ser. Enfim, a angústia em Ser e Tempo é uma disposição fundamental que possibilita ao ser-aí ser em sentido próprio, ao passo que na preleção Que é Metafísica? a angústia é a disposição fundamental que liberaria o descobrimento do nada.

\section{CONSIDERAÇÕES FINAIS}

A partir do exposto anteriormente, apesar das semelhanças claras de tratamento do conceito de angústia entre as duas obras, não seria possível sustentar, também, que há uma

\footnotetext{
${ }^{3}$ Em Sobre a essência do fundamento Heidegger, com efeito, afirma: "O nada é o não do ente, e, deste modo, ser experimentado a partir do ente." HEIDEGGER, Martin. Sobre a essência do fundamento. In: Conferências escritos filosóficos. Trad. Ernildo Stein. Coleção Os Pensadores. São Paulo: Abril Cultural, 1979.
} 
ligeira diferença? Com efeito, Heidegger se limita em Ser e Tempo à analítica do ser-aí, enquanto na preleção o filósofo já sinaliza o pensar do ser.

O tratamento do conceito de angústia segue caminhos diferentes, portanto - embora não opostos -, em Ser e Tempo e em Que é Metafísica?, de acordo com a perspectiva a partir de onde o fenômeno é pensado. Em Ser e Tempo a angústia é tratada como possibilidade de o ser-aí deparar-se com si mesmo, enquanto na preleção a angústia é pensada como disposição que possibilita a manifestação do nada.

Nesse sentido, segundo Richardson, enquanto a angústia em Ser e Tempo desvela o mundo como tal, na preleção, a angústia desvela o ser. Com efeito, a manifestação do nada na aula inaugural, seria, enfatiza Richardson, a revelação do ser. Isso se justificaria na medida em que o nada, assim como o ser, é entendido como o que torna possível a manifestação dos entes como entes. Vê-se assim, segundo Richardson, que a revelação do nada seria a abertura ontológica da verdade, e por isso o esforço para se responder à pergunta acerca do nada seria um esforço para se pensar o ser em sua verdade (RICHARDSON, 2003, p. 202).

Desse modo, a diferença que expomos neste trabalho explicitaria um movimento de transição do pensamento heideggeriano e, juntamente com isso, explicitaria o desdobramento do pensamento do filósofo. Assim, a maneira mais ontológica de se pensar a angústia em Que é Metafísica?, ao invés de indicar uma diferença de pensamento radical, sinalizaria o desdobramento de seu pensamento. Sobre isso, Richardson diz que a mudança de perspectiva feita por Heidegger é perfeitamente coerente com as intenções de seu primeiro trabalho, e, em sentido genuíno, nasce por fidelidade a ele $^{4}$ (RICHARDSON, 2003, p. 207). De acordo com isso, Richardson observa que, embora muitos comentadores admitam uma profunda concordância entre Ser e Tempo e Que é Metafísica?, também seria possível notar uma ligeira diferença. De fato, Ser e Tempo tinha como propósito colocar a questão do ser, mas limitou-se à analítica do ser-aí. Gradativamente a atenção de Heidegger seria absolvida pela questão do ser como tal, de maneira que a transição para a problemática central do ser, na preleção de 1929, já se tornaria patente (RICHARDSON, 2003, 207).

Enfim, a perspectiva existencial de Ser e Tempo se desdobraria, de modo fiel e consequente, na perspectiva ontológica do texto Que é Metafísica. Sendo assim, o modo como a disposição da angústia é tratado na preleção, isto é, como o desvelamento do nada, pode ser lido como o desdobramento do tratamento do conceito de angústia em Ser e Tempo.

\footnotetext{
${ }^{4}$ Em carta enviada por Heidegger a Richardson, o filósofo, ao mesmo tempo que concorda com a distinção entre Heidegger I e Heidegger II, sugerida pelo pesquisador americano, observa, porém, que não se pode entender essa distinção como uma ruptura no curso do pensamento do ser, pois o Heidegger I só se tornaria compreensível partir do Heidegger II e vice-versa.
} 


\section{REFERÊNCIAS}

DUBOIS, Christian. Heidegger: introdução a uma leitura. Rio de Janeiro: Jorge Zahar, 2004.

HEIDEGGER, Martin. "Que é Metafísica?". In.: Conferências e escritos filosóficos. Trad. Ernildo Stein. Coleção Os Pensadores. São Paulo: Abril Cultural, 1979.

- Ser e tempo. Partes I-II. Trad. de Márcia de Sá Cavalcante. Petrópolis: Vozes, 1997, 2 vols. (col. Pensamento Humano).

MACDOWELL, João Augusto. A gênese da ontologia fundamental de Martin Heidegger: ensaio da caracterização do modo de pensar de Sein und Zeit. São Paulo: Editora Herder, 1970.

RICHARDSON, William J. Through Phenomenology to Thought. Fourth Edition. New York: Fordham University Press, 2003.

STEIN, Ernildo. A questão do método na filosofia: um estudo do modelo heideggeriano. 3 ed. Porto Alegre: editora Movimento, 1983. Seis estudos sobre Ser e Tempo. 3.ed. Petrópolis: Vozes, 2005. 